\title{
The Analysis of Amateur Sports Clubs Funding: A European Perspective
}

\author{
By Eric Barget ${ }^{*}$ \\ Sabine Chavinier-Rela ${ }^{\dagger}$
}

\begin{abstract}
A literature review shows that the heterogeneity of financial resources is one of the main characteristics of the third sector in general, and of sports clubs in particular. Nevertheless, there are big discrepancies between clubs and the aim of this paper is to answer the question: why do some clubs succeed in diversifying their financing structure while others rely strongly on member fees? To deal with this topic, four indicators of revenue heterogeneity were first built. A set of explanatory variables had to be selected and afterwards tested according to the step by step OLS method. Performing the econometric test on all the clubs of the database allows the selection of the most appropriate diversification index (Hirschman Index). Afterward, data were processed on the one hand sport by sport, and on the other hand country by country, to identify respectively sport's particularities and national discrepancies. Some of the results were expected, variables like the sporting level of the club, the size of the budget, the organization of sporting events, the percentage of women, being positively correlated with revenue diversification. Nevertheless, other results are more original, it is so in particular for the location of the club, and of the number of employees which do not influence revenue structure in the expected manner. From the results, it is possible to give some recommendations to club's managers looking for a more diversified and stable financing model. We can explain on which variables they should play in a way to get additional revenues.
\end{abstract}

Keywords: Amateur sport clubs, Clubs financial resources, Diversification Index, Diversification factors, Revenues heterogeneity

\section{Introduction}

In economics, few investigations focus on amateur sports clubs, compared to the research on professional sport and sporting events. Although this is easily understandable in an American context, it is more surprising in Europe where sports associations are the basis of the system of sports (Andreff 2007). However, the appearance of the sessions specifically dedicated to amateur sport in the annual conferences of the International Association for Sport Economics and of the European Association for Sport Economists, has shown a growing interest in this issue. Up to date, though, it is only the demand ${ }^{1}$ and the spending (Humphreys and Ruseski 2009) that have been really analysed. From this standpoint, the reference work written by Downward et al. (2009) is innovative, because it addresses sport in its various dimensions (sporting events, professional sport and leisure activities). It devotes a chapter to the supply of sports practice by clubs, goes beyond the scope of non-monetary financing i.e. volunteering (Novotny 2008), and goes

\footnotetext{
${ }^{*}$ Senior Lecturer, CDES/OMIJ - University of Limoges, France.

${ }^{\dagger}$ Lecturer, CDES/OMIJ - University of Limoges, France.

${ }^{1}$ Examples include the work carried out by Michon et al. (1987) in France, Pawlowski and Breuer (2011) and Ruseski et al. (2011) in Germany.
} 
beyond the national perspective ${ }^{2}$. Andreff (2012) subsequently compared supply and demand in two segments of the sports market: subsidized and commercial practice. These are the main contributions to the analysis of the funding structure of amateur clubs from a transnational perspective.

This issue is an opportunity to highlight a distinctive feature of sport clubs: the great diversity of their revenues. This is also one of the criteria that distinguish the organisations of the third sector (including associations). Although it is a very complex field and even if the existing definitions differ in the United States and in Europe (Evers and Laville 2004), it should be remembered that the third sector's distinguishing feature is to carry out a project with a social dimension. The charter of social economy ${ }^{3}$ refers to the diversity of revenue as one of the five distinctive features of this sector ${ }^{4}$. Diversifying revenue consists, in this case, of using revenue from different origins (members, public authorities and private partners, etc.), not only in order to increase the revenues of the organisation (the sports club) but also to stabilise its funding. This principle is identical to that of market finance, in which one seeks to have a highly diversified portfolio of assets in order to make it less risky, more profitable, and therefore more sustainable in the long term (Amit and Livnat 1988). From this point of view, revenue diversification could then be considered as a positive dynamic, unlike revenue concentration, which is typical of clubs with a more fragile economy, or clubs that are stagnating.

This article, therefore, intends to analyse the budget structure of sports associations and their determinants. Our working hypothesis is that revenue diversification is a more stable solution for clubs than focusing on one single revenue source (or just a few), because revenue concentration makes clubs dependant. This work is based on a study carried out for the European Commission (Eurostrategies 2011a), the purpose of which was to identify the main obstacles to the development of sport markets in the Member States. It analyses the cross-border differences and the discrepancies identified between one sport and another. The data relates to one year, per sport and per country. It thus makes it possible to provide an interesting instantaneous cross-sectional analysis. The first part of this strictly empirical article offers a review of the literature about revenue diversification in the third sector and explains the main variables which influence the degree of diversification of these sources of funding observed in sport clubs. The second part is about the methodological framework selected for the analysis. The concept of revenue diversification will be clarified and the major types of financing in associations will be differentiated. Four indicators of the degree of revenue diversification will be suggested. The methods of data collection from different sports clubs across Europe will be detailed. The third part presents the econometric tests that were initially performed on all the data, in order to select the

\footnotetext{
${ }^{2}$ An example of such national studies could be for France the research of Bourg and Nys (2012).

${ }^{3}$ CEGES - Conseil des Entreprises et groupements de l'économie sociale (Council of companies, employers and groups of the social economy) (1995) La charte de l'économie sociale - Charter of Social Economy. 10 May 1995. www.ceges.org.

${ }^{4}$ The five criteria selected are: freedom of membership, individual not-for-profit orientation, democratic management (one person - one vote), collective utility of the project, diversity of revenues (CEGES 1995). See also Lipietz (2000).
} 
most relevant indicator of diversification. The dataset was then processed for each sport on the one hand, to identify the differences between the disciplines and for each country on the other hand, in order to analyse national specificities. The fourth part discusses the results obtained and suggests possible ways of increasing not only the overall amount of club revenues, but also their revenue diversification, as a guarantee of an enhanced financial stability.

\section{Literature Review}

\section{Overview of Revenue Diversification as the Primary Characteristic of Sport Clubs}

Literature about the third sector generally considers the issue of funding to be important (Borzaga and Defourny 2001). Unlike the private commercial sector, financial revenues are not a goal for a third-sector organisation; on the contrary, they are a mean of pursuing its social purpose (Colette and Pigé 2007). Whereas customer sales are the only source of revenue for profit-oriented companies, the leaders of social economy organisations are required to call upon a great variety of economic agents (beneficiaries of their supply of services, public authorities through subsidies and private companies via patronage, etc.). The revenue diversification which results from this constraint was highlighted, in particular, by Tchernonog $(2007,2013)$. This study, which focused on the associations based in France and covered all subsectors of the associations' sector, showed that revenues from sales of goods and services represented $60.6 \%$ of the income, public subsidies $24.7 \%$, subscriptions $10.7 \%$ and donations and patronage $4 \%$. Studies conducted in other European countries (Defourny and Laville 2007) have led to the same conclusion: a significant spread of funding.

It was established that most of the supply of sports came from not-for profit clubs. In Slovenia, therefore, they represent $70.6 \%$ of the funding devoted to the supply of sport, whereas business-oriented private companies bring in $18.2 \%$ of the revenue and public authorities 11.2\% (Bednarik et al. 2010). Given the importance of this, it is surprising that knowledge of the issue of funding sports clubs remains both wide-ranging and incomplete. Work carried out at the national level in each country turns out to be very heterogeneous, both from the point of view of the study subject itself (sports, countries, revenues, expenditures and volunteering, etc.) and from the methodology used (different disciplinary fields are used: economics, management and sociology, etc.). In these conditions, it is difficult to give precise figures on the funding of associations that could be comparable in various European countries ${ }^{5}$. The survey proposed by Downward et al. (2009) on this subject, shows, however, that the heterogeneity of sport club revenues is a specificity that all countries have in common. In addition to

\footnotetext{
${ }^{5}$ It enables us to list the work conducted in different European countries gathered in the collective book directed by Heinemann (1999), Parro et al. for Italy, Puig et al. for Spain, Leroux et al. for France, Stamm et al. for Switzerland, Heinemann et al. for Germany (see also Horch (1998) and Breuer (2007)), Taks for Belgium, Ibsen for Denmark, Skirstad for Norway, Koski for Finland, and Slack (1997) for the United States.
} 
volunteering $^{6}$, the same items of financial resources were identified: subscriptions, commercial activity (hospitality, sponsorship and sales of services, etc.) and subsidies paid by the public sector (directly via budget allocation from the Ministry or indirectly via the redistribution of revenue as a result of taxing gambling and betting).

The report delivered to the European Commission (Eurostrategies 2011b) on the barriers to the development of sports markets ${ }^{7}$ confirmed that there are many funding sources and that there is a complex interplay despite the limited number of stakeholders (Figure 1). Members are the main contributors (63\%) via their subscriptions (which represent, for example, $55 \%$ of the total amount of revenue in tennis clubs, gymnastics clubs and swimming clubs) and the purchase of services, including lessons. Public authorities play a significant role: $18 \%$ of club funding is provided by local authorities and the State, with wide discrepancies between sports. The other sources of funding are more modest: $9 \%$ from sponsorship, patronage and donations, and $2.2 \%$ from federations (including the flows of money related to the solidarity mechanisms). The item "Miscellaneous" is representing $8 \%$ of club's funding. The importance of member fees and the weakness of revenue from the sale of goods and services in sports clubs compared to other associations of the third sector should be noted. Nevertheless, it has been demonstrated that this average profile covers significant discrepancies between countries and sports: thus, member fees represent $70 \%$ of tennis club revenues in Germany and Spain, as opposed to 55\% in the Netherlands and 50\% in France. On the other hand, they account for $70 \%$ of gymnastic club revenues in the Czech Republic, Spain and Germany, but only $45 \%$ in France.

\footnotetext{
${ }^{6}$ Authors affirm the importance of volunteering: 2.8 million volunteers in Germany, more than one million in France and 700,000 in Italy.

7 This study on federated grassroots sports (i.e. practiced in clubs affiliated to federations), was commissioned by the Directorate General for Education and Culture (DG EAC) of the European Commission (EC) within the competence of which sport falls, and by the EC's Directorates-General "Internal Market and Services" (DG MARKT) and "Competition" (DG COMP). It was undertaken by a consortium composed of Eurostrategies, Amnyos, the Centre for the Law and Economics of Sport (CDES) and the Deutsche Sporthochschule Köln. The data collection on which this article is based on was performed in the framework of this research study.
} 
Figure 1. Sports Club Funding Channels in Europe

The funding channels subject to regulations

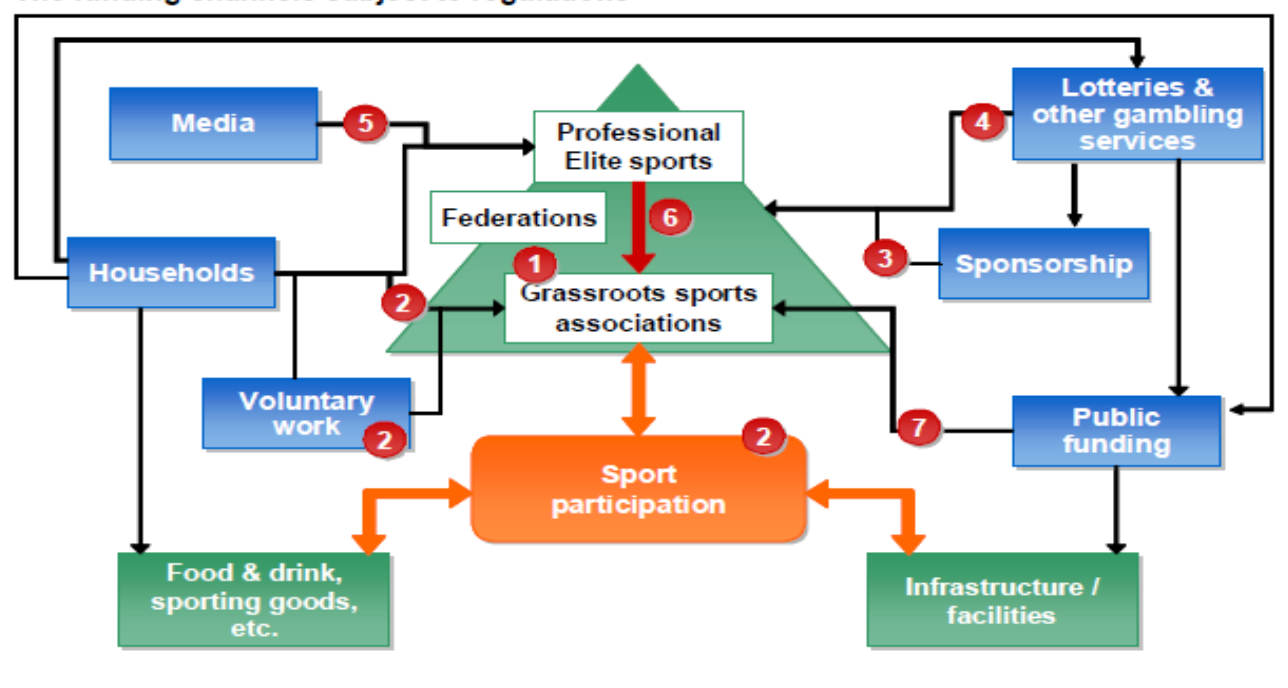

Source: Eurostrategies (2011b).

In addition to static analysis, the dynamic process of diversification of club revenues was analysed in Germany ${ }^{8}$. The results of these longitudinal studies (Breuer 2009, Wicker et al. 2012) established, in particular, that there are complex interplays between the various sources of revenue. Larger donations were accompanied by revenues relating to sporting services (club member fees and lessons), which could be characterised as the traditional sports club model. Furthermore, there was positive interaction between subsidies, donations and the revenues linked to economic activity (including sponsorship). This reflected the fact that dynamic clubs are able to call on both public and economic partners. The authors also observed that commercialisation and modernisation of sports clubs were increasing.

Despite the flow of funds that come into amateur sport clubs $(46.6 \%$ of the money injected into the sports sector, in general), the funding of sports clubs seems fragile. The funding is, in fact, increasingly focused on high-level sport shown as a spectacle, which makes some authors (Andreff et al. 2009) fear that a separation may occur between the base and the top of the sports pyramid that characterises the European model of sport. In this context, it is crucial to analyse how to optimise the funding of grassroots sport clubs by diversifying its origins.

\section{Explanatory Factors of Clubs Financing Structure}

The level of concentration or, conversely, the level of diversification of revenues varies significantly from one club to another: this raises the question about the explanatory factors of such disparities and, more specifically, the question about the decisive variables in the clubs' ability to seek new ways of

\footnotetext{
${ }^{8}$ A survey is regularly carried out at the national (German) level and supplied to a panel of managers of non-profit sports organizations composed among the 91,091 sports clubs in Germany.
} 
developing. No literature has been developed on this topic, but although no econometric test has been performed yet to the best of our knowledge, some results could however help identifying factors, and we could test their real influence afterwards. Several studies were conducted at the European level in order to quantify the economic weight of sport, firstly at the request of the Council of Europe (Andreff et al. 1995), then at the request of the French Secretary of State for Sports (AMNYOS 2008, Andreff et al. 2009).

These works focused on overall sports expenditure and not exclusively on the funding of amateur sport associations. It should be remembered, however, that household spending on sport is significant (generally, more than half the national spending on sport) and that a major part of this spending is to the benefit of the clubs in the form of subscriptions and purchases of various services. It should also be remembered that volunteering is one of the backbones of associations, the strength of which will have an impact on the budget structure. The impact of the volunteering dynamic (positive or negative) on club finances, therefore, seems important to study. De Knop et al. (2004), when analysing the managerial skill of Flemish sports associations, emphasised the role that club governance plays on its financial situation and its ability to call on a great variety of revenues. It forces sport clubs to develop from being traditional sports associations towards more professional organisations efficient in providing sport services, and to becoming a hiring association. All the works mentioned below come back to the role of employees, who work alongside volunteers in bringing in club revenues.

Augustin and Garrigou (1985), Ion (2001) and Anheier (2005) pointed out that the history of the organisation, along with its political, economic and social environment, should also to be taken into account in understanding the budget. The general approach of the club and its objectives are also decisive. Skirstad and Chelladuraï (2011) made an analysis showing that in Norwegian clubs, various opposing logics such as the amateur, professional and commercial may coexist. This justifies the introduction of variables such as the level of practice and competition, and types of the club's commercial activities, such as hiring equipment, as well as organising sporting and non-sporting events. Amis and Slack (1996) and Slack (1997) emphasised that the size of the club and its ageaffect the diversity of its revenues.

In France, Tchernonog (2007) or Andreff et al. (1995) have already observed that the number of employees, the number of members, and the participation or not in high-level competitions, are influencing the degree of funding diversification. The stronger or weaker structuring of the club (especially the number of employees) and the sporting level would, therefore, matter. On the other hand, when the size of the club grows, the share of revenues from business and of subsidies increases, whereas the share of members' fees decreases. Tchernonog shows that the budgets of hiring clubs are higher $(€ 104,600$ against $€ 17,000$ for the clubs that do not hire staff), and that these levels are reached thanks to a necessary diversification of revenues. The presence (or the proportion) of women in clubs is a factor of diversity, owing to their involvement in seeking additional funds, especially by organising sporting and non-sporting events (Tabariés and Tchernonog 2004). Chantelat's work (Chantelat 2001) focuses on 
club expenditure rather than their revenues; however, it indicates that the combination of three types of expenditure (sport-related, social and economic) makes it possible to draw up a typology of clubs.

In Germany, researches (Wicker et al. 2010) focused on the expenditure of club members, which seems to vary significantly depending on the sport (€7,902 for horse riding and $€ 338$ for badminton). These differences can only partly be explained by the differences in the amount of members' fees and services purchased in the club (lessons and equipment, etc.). Indeed, the purchase of clothes and equipment, spending for transportation and accommodation, etc. are taken into account, just as in similar studies led by Michon et al. (1987) in France, as well as by Humphreys and Ruseski (2009) in the United States. Nonetheless, the sport itself is an influential determinant of the amount of the spending made in the club (members' fees, lessons and equipment sales, etc.) and, indirectly, of the funding structure of clubs. This is why we needed to look at several sports in this study. In tennis, for example, the sales of goods and services is a tradition which is made possible by the presence of a club house, which is less easy in some sports requiring the use of gymnasia and premises to be shared with clubs of other disciplines. The fact that the club has at its disposal appropriate resources in terms of sport facilities (Wicker et al. 2009), and especially a clubhouse, would therefore have an impact on the club's ability to develop a new income (from business), which we test at a European level in this article. Furthermore, it has been demonstrated that gender has a strong influence on spending: female members spend more for sport, although they have lower incomes. The percentage of women in clubs will therefore have to be considered as a potential factor influencing the budget structure.

This review of literature found that although funding of sport clubs is based mainly on subscriptions, some associations do manage to diversify their revenues and consequently increase their budget. It also appears that knowledge of determining factors related to the clubs' budget structure is incomplete, which can be explained by the fact that sports economists are more focused on the participants demand ${ }^{9}$ for sport, rather than on club supply. Despite this, we were able to identify some factors which may potentially have an impact on the way sports clubs finance themselves, and we will try to test their influence using econometrics.

\section{Methodological Framework: An Adaptation of Tools from Finance and International Economics}

\section{The Effects of Diversifying Revenues on Clubs Financial Vulnerability}

The model refers to one of the most prominent theories pertaining to risk within the financial economic literature which is the Capital Asset Pricing Mode funded by Markowitz in 1952. This methodological framework had been

\footnotetext{
${ }^{9}$ Among the research aimed at identifying the socio-demographic determinants of the demand for sport, see also Breuer et al. (2010), and Breuer and Pawlowski (2011).
} 
implemented to nonprofit organizations by Kingma (1993) and improved by Wicker et al. (2012) and Wicker et al. (2015). The choice of a risk-revenue package (the optimal combination of revenue streams) for a sport club is the same as the finance problem of choosing the optimal combination of two assets (stocks).

Wicker et al. (2015) have shown that revenue diversification reduces financial volatility (i.e. fluctuation of revenues from period to period), the effects being higher for what they call club-specific volatily (related to factors internal to the club) than for systematic volatility (as a results from changes in the broader economy that affect all clubs). The model can be written as follow: $\sigma_{T R}^{2}=x_{A}^{2} \sigma_{A}^{2}+x_{B}^{2} \sigma_{B}^{2}+2 x_{A} x_{B}\left(\operatorname{Cov}_{A B}\right)$ where $\sigma_{T R}^{2}$ is the variance of the club's total revenues, $x_{A}$ and $x_{B}$ are the percentages of the club's revenues coming from streams $\mathrm{A}$ and $\mathrm{B}, \sigma_{A}$ and $\sigma_{B}$ are standard deviations of A's and B's revenues, and $\operatorname{Cov}_{A B}$ is the covariance between the revenues of $\mathrm{A}$ and $\mathrm{B}$. It had been shown that, providing that $\operatorname{Cov}_{A B}<1$, the standard deviation in total revenues $\sigma_{T R}^{2}$ is less than the weighted average of the standard deviations of the two individual revenue stream. Therefore, there are benefits to diversification, moreover if this new revenue stream is not perfectly correlated with the original revenue stream. The model had been generalized to the case of $N$ revenue sources by Ross et al. (2008). They concluded from their research that, as $N$ goes to infinity, the weighting on the variance term goes to zero while the weighting on the covariance term goes to 1 . Thus, while the variance of any particular revenue stream can ultimately be diversified away by adding more revenue streams (club specific volatility will be reduced), the covariance of that stream with other revenue streams cannot diversified away (it is driven by broader economic conditions so that systematic risks for clubs will remain).

Other researchers (Cordery and Baskerville 2013, Greenlee and Trussel 2000, Trussel 2002), tried to identify determinants of financial vulnerability within amateur sports clubs and also found that revenue diversification plays a crucial role. In respect with these results on the effects of revenue diversifying on financial risk, we will focus, in this articles, on variables internal to the club that explain why some clubs are able to diversify their financial resources in comparison with other clubs. According to Wicker et al. (2015) it is a way for these clubs to increase their financial stability over time.

\section{Measuring Income Diversity}

Diversifying sports club revenues means calling on different resources in order to increase the budget and make it more stable in the long-term. As sports association revenues are numerous, it was necessary to draw up broad categories that we aimed to harmonise. The literature review revealed that the typologies of the financial resources of sports clubs were very heterogeneous, which considerably impaired the readability and comparability of the work already mentioned. The following typology was adopted here: 1) member fees that opens the possibility of organised activity for participants; 2) subsidies from local 
authorities because of in return for the general missions fulfilled by the club and, more broadly, its social utility; 3) sponsorship and patronage from private companies that reflect what the club represents for business partners; 4) other business revenues which represent the ability of the club to generate additional products through the marketing of certain goods and services. This last category includes such items as payments from the national federation, the sale of food and drink, the sale of services, revenue from sporting events, the sale of products (material and clothes, sometimes with the club emblem) and various revenues. Subsequently, these various components will first be calculated separately, before being combined under the heading "Business revenue".

Figure 2. The Four Diversification Indexes

$$
\frac{1 \text {-Hirschman Index }}{H_{1}=\sqrt{\sum_{i=1}^{N}\left(\frac{x_{i}}{X}\right)^{2}}}
$$

With $x_{i}$ the value of revenues of category $i$ $X$ the total value of revenues $N$ the number of revenues categories (here $N=4$ )

\section{2- Hirschman Normalised Index}

$N-H 1=\frac{\sqrt{\sum_{i=1}^{N} P_{i}^{2}-\sqrt{\frac{1}{N}}}}{1-\sqrt{\frac{1}{N}}}$

With $P_{i}=\frac{x_{i}}{X}$ i.e the proportion of

revenues of category $i$ in the total value of revenues

From these broad categories, some indicators were chosen in order to calculate the level of diversification (or the opposite, of concentration) of sports club revenues. To our knowledge, the literature on sports economics has not tried to develop such indicators. Therefore, it was necessary to refer to the fields of urban and regional economics, international economics, and finance. Four indices were selected. Their transposition to sport gives the formulae suggested in Figure 2.

The index created by Albert Hirschman (1945) has been widely used to measure the degree of concentration of products and trade (Massell 1970, Kingston 1976, Svedberg 1991, Stanley and Bunnag 2001). Taking into account the formula proposed above, the minimal value of $H_{1}$ corresponds to $1 / \sqrt{N}$, when the variance is equal to zero and when all the units are identical.

Owing to the fact that four groups of revenue are considered, the index here takes a minimal value of 0.5 . However, the value tends towards 1.0 , when an 
income group is much higher than the others. The normalised Hirschman Index $(\mathrm{N}-\mathrm{H} 1)$ could also be used as a relative measure of diversification, by expressing its value between 0 (a single revenue group represented in the club budget) and 1 (perfectly equal distribution between the four product categories). For its part, the Ogive Index is especially used to measure industrial diversification or that of exports (Attaran and Zwick 1987). It measures the deviation from a distribution average. This index is between 0 , when resources are equally distributed and therefore funding is diversified, and 3, which reflects a high concentration on a particular revenue group. Lastly, the Entropy index is very much used in finance, trade, communications and science. It is particularly used by industrial groups to carry out diversification and rationalisation analyses (Batsch 1993). The maximum value of ENT represented by $\log _{2} \mathrm{~N}$ is reached when the Pi are equal. Conversely, if one product $i$ provides all revenues, $\mathrm{P} i=1$, then $\mathrm{ENT}=0$ and the concentration is maximum ${ }^{10}$.

\section{The Econometric Model and Explanatory Variables}

The model tested is given below. The regression was firstly performed on the entire clubs sample, taking successively each of the four diversification indices previously presented as the dependent variable $\left(D I V_{i}\right)$. This made it possible to retain the index which gave the best results in terms of statistical significance to then perform regressions by country and by sport. The dependent variables $^{11}$ were grouped into categories (Table 1). CARAC $i$ is a vector of grouping variables relating to general club characteristic. $M E M B_{i}$ is a vector of variables characterising club members. $L E V i$ is related to competition level. $S T R U C_{i}$ brings together factors relating to the club organisation and structure. $R E V_{i}$ corresponds to the amount and nature of the revenue generated by the club (especially, the revenue related to members and marketing). $E X P_{i}$ records the distribution of the club's major items of expense.

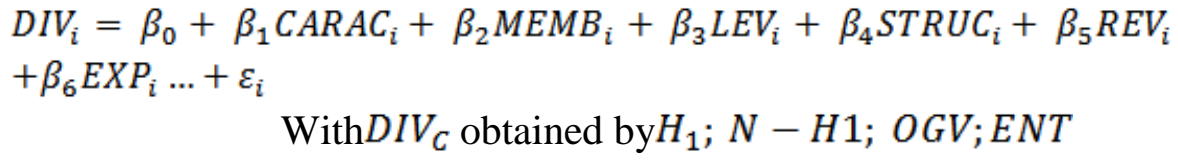

With $D I V_{C}$ obtained by $H_{1} ; N-H 1 ; O G V ; E N T$

\footnotetext{
${ }^{10}$ This entropy index is, therefore, an indicator of diversification, since the higher it is, the more the funding structure is diversified, whereas the first three indicators (Hirschman, normalised Hirschman and Ogive) are concentration indices, since the higher they are, the more the funding structure will be concentrated. We decided to take the complement of these three indices in order to standardise reading and to have 4 diversification indices, which will help to interpret the results.

${ }^{11}$ Some variables in the table are expressed in logarithms. These variables take high values and then the logarithm limits the differences in value.
} 
Table 1. Explanatory Variables Tested in the Model

\begin{tabular}{|c|c|c|c|}
\hline Vector & Variables & Title & Nature \\
\hline CARACTERISTICS & OMNI & 1 for a multisport club, 0 otherwise & Dummy \\
\hline \multirow[t]{2}{*}{ "CARAC" } & AGE & Age of the club & Numeric \\
\hline & URBAN & Dummy variable 1 if urban area, 0 if rural & Dummy \\
\hline MEMBERS & ln MEMBERS & Logarithm of the number of club's members & Numeric \\
\hline \multirow[t]{3}{*}{ "MEMB" } & $\%$ FEM & Percentage of females & Numeric \\
\hline & MEMBINC & 1 if increase of the number of members over the last 6 years, 0 otherwise & Dummy \\
\hline & MEMBSTAB & 1 if stability of the number of members over the last 6 years, 0 otherwise & Dummy \\
\hline LEVEL & HIGHNUM & Number of high level sportsmen in the club & Numeric \\
\hline \multirow[t]{2}{*}{ "LEV" } & HIGHLEV & 1if the club is part of national or international competitions, 0 otherwise & Dummy \\
\hline & LOWLEV & 1 if the club is part of local or regional competitions, 0 otherwise & Dummy \\
\hline STRUCTURE & CLUBHOUSE & 1 if a club house is available, 0 otherwise & Dummy \\
\hline \multirow[t]{3}{*}{ "STRUC" } & EMPLOY & Number of employees in the club & Numeric \\
\hline & VOLINC & 1 if increase in the volunteers number over the last 6 years, 0 otherwise & Dummy \\
\hline & VOLSTAB & 1 if stability in the volunteers number over the last 6 years, 0 otherwise & Dummy \\
\hline REVENUE & $\ln$ BUDG & Logarithm of the club's budget & Numeric \\
\hline \multirow{5}{*}{ "REV" } & FEESAV & Average fee paid to the club by members & Numeric \\
\hline & $\ln$ FEES & Logarithm of club's resources coming from member fees & Numeric \\
\hline & RENTFACI & 1 if the club rents sport facilities, 0 otherwise & Dummy \\
\hline & EVESPO & 1 if the club organizes sporting events, 0 otherwise & Dummy \\
\hline & OTHEREVE & 1 if the club organizes non-sporting events, 0 otherwise & Dummy \\
\hline EXPENSES & $\%$ WAGE & Percentage of expenditures related to wages (wages/total expenditures) & Numeric \\
\hline \multirow[t]{4}{*}{ "EXP" } & $\%$ EQUI & Percentage of expenditures related to purchase of equipment & Numeric \\
\hline & $\%$ FACI & Percentage of expenditures related to facilities & Numeric \\
\hline & \%TRANS & Percentage of expenditures related to transportation & Numeric \\
\hline & $\%$ FEDE & Percentage of expenditures benefiting to the national federation & Numeric \\
\hline
\end{tabular}


This method consists of applying the Ordinary Least Squares (OLS) approach. It helped identify the significant variables (the list is shown in Table 1), step by step, from a variable selection process that adds the most significant variable and removes that which is least, until the model is optimal. These variables were chosen with regard to the literature review.

\section{Data Collection}

The data was collected during the study on the funding of grassroots sport in Europe (Eurostrategies 2011a, 2011b). As part of a "bottom up" type analysis of amateur sports club funding, it was necessary to focus on just some sports and some countries, since comprehensiveness was obviously impossible. Countries were chosen on the basis of their ability to represent a specific funding model. Germany and The Netherlands represent countries where people do a lot of sport and where there is significant public and private funding, with strong recognition of the social role of sport. Spain was chosen among the countries that were characterised by fewer people doing sport, significant funding for households and lower public support owing to lower recognition of the externalities of sport. The Czech Republic was chosen from those countries where there is also low social demand for sport, but with a lower level of sports spending by households and public authorities. France was also chosen because of the particularities of its sports model, which is close to the first group, but with higher public spending and lower households spending ${ }^{12}$.

The choice of sports was made on the basis on the level of participation in these different sports in the European Union. The most popular sports were chosen, i.e. those that appear at least four times in the ten most popular sports in each EU country ${ }^{13}$. Four sports in common were selected for all the member states: football, basketball, tennis and gymnastics. Between swimming and athletics, a fifth sport was chosen for each country in the sample, based on the number of participants. Data was collected through a questionnaire sent to 600 clubs by sport. It was a random sample, stratified according to two criteria. The first was club size, assessed for each sport according to the average number of members per club and adjusted according to the opinion of correspondents from each federation ${ }^{14}$. The second concerned the urban or rural character of the municipality where the club was located. The questionnaire was distributed between May and September 2010 via the relevant national sports federation, in order to improve the rate of return and the quality of the information input. Though the questionnaire, which was translated into each national language, is too long to be reproduced here in its entirety, it is possible to have an overview of its structure: presentation of the context and characteristic of the club, the number and

\footnotetext{
${ }^{12}$ In the study commissioned by the EU, Lithuania, Denmark and the UK were also part of the countries surveyed. The collected data were not, however, used in the context of this article.

${ }^{13}$ Other criteria helped further reduce the sample group of the selected sports: individual or collective sports, technical level, types of members, participation costs, cultural aspects, etc.

${ }^{14}$ These are the federations that chose the clubs by ensuring their equal distribution among clubs of various sizes (a third of small, average and large clubs) and among locations (half located in urban areas and half in rural areas).
} 
profile of the members, the club income and how it develops, the items of expenditure, the business of the club and its major projects, and the prospects for development.

Difficulties were encountered during the survey, as some federations were reluctant to disseminate details of clubs and others had listings that needed updating. In addition to the summer period, when associations are not easily contactable, the length of the questionnaire discouraged some clubs from replying (31 questions, mostly multiple response categories). Financial considerations remained sensitive and suspicions persisted about the idea of answering questions as to the origin and use of club income. The obstacle was even more real in that clubs are not always managed in a transparent manner (Andreff 2007). In total, there were 1,454 completed questionnaires (Table 2), with an unequal distribution between countries and between sports. The collection of data worked well in Spain, France, the Czech Republic and The Netherlands. The number of questionnaires collected from Germany was low; however, this was mitigated by using, whenever possible, data collected from national surveys ${ }^{15}$, which may have dissuaded them from responding to the European survey. The collection was even more limited for athletics than for other sports, as fewer countries chose it, preferring swimming. From the point of view of the representativeness of clubs, comparison with the average club size with the national statistics available to federations showed a slight bias in favour of major clubs, which were significantly over-represented in the sample ${ }^{16}$. That was probably explained by the time and resources required to complete the questionnaire.

Table 2. Number of Clubs that Answered the Questionnaire

\begin{tabular}{|c|c|c|c|c|c|c|c|}
\hline & \multicolumn{6}{|c|}{ Sports } & \\
\hline Country & Football & Basketball & Tennis & Gymnastics & Swimming & Athletics & Total \\
\hline France & 72 & 104 & 69 & 92 & 73 & 32 & 442 \\
\hline $\begin{array}{l}\text { Czech } \\
\text { Republic }\end{array}$ & 106 & 25 & 36 & 16 & 18 & 17 & 218 \\
\hline Germany & 19 & 3 & 9 & 14 & 6 & 6 & 57 \\
\hline $\begin{array}{l}\text { The } \\
\text { Netherlands }\end{array}$ & 111 & 24 & 34 & 0 & 34 & 0 & 203 \\
\hline Spain & 105 & 114 & 109 & 100 & 105 & 1 & 534 \\
\hline Total & 413 & 270 & 257 & 222 & 236 & 56 & 1,454 \\
\hline
\end{tabular}

Over all of the clubs considered, the average budget was €92,006. Significant differences appeared depending on the country, with the highest budgets being found in The Netherlands $(€ 107,082)$ and the lowest in the Czech Republic $(€ 36,284)$. The countries with a higher GDP per capita also had a more significant average budget for sports clubs, confirming the results of Andreff et al. (2009). The budget was related to the number of members;

\footnotetext{
${ }^{15}$ Breuer (2007), Breuer (2009), and Breuer et al. (2010).

${ }^{16}$ The difference between the average number of members in the surveyed sports clubs and national statistics is relatively limited for some countries (493 compared to 396 in The Netherlands), and sometimes even sharper (409 compared to 95 in Spain). Such differences can also be found in financial data; the average club budget in France was here estimated at $€ 64,871$, while Tchernonog had calculated it at $€ 33,160$ (even if this last figure was for 2007).
} 
associations with fewer than 300 members had $€ 32,750$ in average income, whereas those with more than 300 members had $€ 141,563$. The average membership was 369 . There was a very strong heterogeneity in its distribution: The Netherlands and Germany tended to increase this figure by virtue of the presence of large multidisciplinary clubs that could also be found in the Czech Republic, one of which had more than 12,000 members.

On the other hand, it was fairly homogenous between sports: with 254 members for both basketball and swimming clubs. Furthermore, clubs with no employees had an average budget of $€ 38,716$, compared to $€ 105,782$ for employer associations, which confirmed their need and the ability to generate new income. The budget structure was as follows: $56.4 \%$ from membership, $14.1 \%$ from public subsidies, $11.8 \%$ from sponsorship and patronage, and $17.7 \%$ from business revenues. This very much shows a diversity of income, even if subscriptions represented more than half the funding received by amateur clubs. As far as registration fees were concerned, football and basketball were the sports with the lowest fees, as they are team sports: $€ 54$ and $€ 61$ respectively. The fees rose to $€ 75$ for tennis and $€ 86$ for athletics. Finally, the most expensive sports for players were those requiring expensive facilities, i.e. swimming (€106) and gymnastics (€127).

\section{The Main Results of Econometric Tests}

\section{The Factors Determining the Income Diversity of European Clubs}

The results obtained (Table 3) were relatively close, according to the diversification indices used, confirming what had already been established by Ben Hammouda et al. (2006). However, it should be noted that the normalised Hirschman Index had a very low explanatory power $\left(\mathrm{R}^{2}=0.0233\right)$ and that few variables stand out. In contrast, there were strong similarities between the Entropy and Ogive Indices for the correlation coefficients, and also for variables that proved to play a significant role on concentration (or to the reverse diversification) of income. As $\mathrm{R}^{2}$ was highest for the Hirschman Index (0.3473), it was used as the sole dependent variable during the following stages, making it possible to compare sports and countries with each other.

Out of 25 variables tested, 13 appeared to be income diversification/ concentration factors of the sports associations studied (whereas the others gave no significant results).

The members profile has finally a limited influence on the nature of financial revenue sources, even if the number of members seems to be a factor of diversification when the Entropy Index is held as dependant variable. On the other hand, the competition level is positively related with revenue heterogeneity, whatever the diversification index that is used. So, the number of high level sportsmen member of the club (HIGHNUM), as well as the fact that the club plays at the national or international level (HIGHLEV), are an opportunity, as well as a necessity, of increasing commercial resources (tickets sales, sponsorship ...). When it comes to variables related to the management of the club and its professionalization, it appears that a club house (CLUBHOUSE) is a valuable 
asset in a way to market goods and services and to optimize revenues. It is on the other hand surprising to notice that in contradiction with lots of previous researches, the number of employees (EMPLOY) as well as a positive dynamics of voluntary works (VOLINC) do not seems determining. It could mean that it is more the fact to be or not an employer rather than the number of employees and the efficiency of volunteers rather than their number that is important. This hypothesis could be tested in future researches. As regards variables relative to revenues of the club, the amount of the budget expressed in logarithm (lnBUDG) shows a "size effect", and also indicates that there is no "substitution effect" of the new resources on the traditional revenues of the club (member fees). Therefore, the most dynamic managers succeed in combining financing flows from various origins. It is moreover why the organization of sporting events constitutes an opportunity to generate new revenues with the sale of tickets, drinks and food, byproducts, what has already been established by (Bourg and Nys 2012).

Table 3. Explanatory Variables for all Clubs

\begin{tabular}{|c|c|c|c|c|c|c|c|c|c|}
\hline \multirow{3}{*}{\multicolumn{2}{|c|}{ EXPLANATORY VARIABLES }} & \multicolumn{8}{|c|}{ DEPENDANT VARIABLE / LEVEL OF FINANCIAL DIVERSIFICATION } \\
\hline & & \multicolumn{2}{|c|}{ HIRSCHMAN } & \multicolumn{2}{|c|}{ HIRSCHMAN NORMALISED } & \multicolumn{2}{|c|}{ OGIVE } & \multicolumn{2}{|c|}{ ENTROPY } \\
\hline & & Parameters & P-value & Parameters & P-value & Parameters & P-value & Parameters & P-value \\
\hline \multicolumn{2}{|c|}{ CONSTANT } & 4.3850 & $<.0001^{* * *}$ & 3.67275 & $<.0001^{* * *}$ & 4.93620 & $<.0001^{* * *}$ & 4.57068 & $<.0001^{* * *}$ \\
\hline CARAC & \begin{tabular}{|l} 
OMNI \\
URBAN
\end{tabular} & -0.0219 & $0.0284^{* *}$ & -0.09920 & $0.0445^{* *}$ & -0.09063 & $0.0626^{*}$ & -0.06728 & $0.0269 * *$ \\
\hline MEMB & \begin{tabular}{|l} 
In MEMBERS \\
MEMBINC \\
MEMBSTAB
\end{tabular} & -0.01475 & 0.1495 & -0.09496 & $0.0427^{* *}$ & 0.06729 & $0.0209 * *$ & -0.04648 & 0.1335 \\
\hline LEV & $\begin{array}{l}\text { HIGHNUM } \\
\text { HIGHLEV }\end{array}$ & $\begin{array}{c}0.0001 \\
0.04673\end{array}$ & $\begin{array}{l}0.0140^{* *} \\
0.0002^{* * *}\end{array}$ & 0.09502 & $0.0459^{* *}$ & 0.00096 & $0.0004^{* * *}$ & $\begin{array}{l}0.00031 \\
0.12175\end{array}$ & $\begin{array}{c}0.0661^{*} \\
0.0010^{* * *}\end{array}$ \\
\hline STRUC & CLUBHOUSE & 0.2050 & $0.0643^{*}$ & & & & & 0.06557 & $0.0456 * *$ \\
\hline REV & $\begin{array}{l}\text { In BUDG } \\
\text { In FEES } \\
\text { RENTFACl } \\
\text { EVESPO }\end{array}$ & $\begin{array}{c}0.1234 \\
-0.12056 \\
-0.0444 \\
0.03418 \\
\end{array}$ & $\begin{array}{l}<.0001^{* * *} \\
<.0001^{* * *} \\
0.0001^{* * *} \\
0.0085^{* * *}\end{array}$ & & & $\begin{array}{l}0.51477 \\
-0.55587 \\
-0.19500 \\
0.16389 \\
\end{array}$ & $\begin{array}{l}<.0001^{* * *} \\
<.0001^{* * *} \\
0.0003^{* * *} \\
0.0069^{* * *}\end{array}$ & $\begin{array}{c}0.30998 \\
-0.31188 \\
-0.15647\end{array}$ & $\begin{array}{l}<.0001^{* * *} \\
<.0001^{* * *} \\
<.0001^{* * *}\end{array}$ \\
\hline EXP & $\begin{array}{l}\% \text { WAGE } \\
\% \mathrm{FACl}\end{array}$ & $\begin{array}{l}-0.05393 \\
-0.05929 \\
\end{array}$ & $\begin{array}{l}0.0039^{* * *} \\
0.0102^{* *}\end{array}$ & $\begin{array}{l}-0.18360 \\
-0.17858 \\
\end{array}$ & $\begin{array}{c}0.0061^{* * *} \\
0.0469^{* *}\end{array}$ & 0.14794 & $0.0121^{* *}$ & $\begin{array}{l}-0.17496 \\
-0.17725\end{array}$ & $\begin{array}{c}0.0020^{* * *} \\
0.0117^{* *}\end{array}$ \\
\hline & $n=1454$ & \multicolumn{2}{|c|}{$R^{2}=0.3473$} & \multicolumn{2}{|c|}{$R^{2}=0.0233$} & \multicolumn{2}{|c|}{$R^{2}=0.2945$} & \multicolumn{2}{|c|}{$R^{2}=0.2940$} \\
\hline
\end{tabular}

Note : the coefficient of variables AGE (âge of the club), \%FEM (percentage of women), LAWLEV (club involved in local or regional competitions), EMPLOY (number of employees in the club), VOLINC (increase in the number of volunteers), VOLSTAB (stability of the volunteers number), FEESAV (average memberfees), OTHEREV (if the club organizes non-sporting events), \%EQUI (percentage of the spending dedicated to equipment), \%TRANS (percentage of the spending dedicated to transportation), \%FEDE (percentage of expenditures benefiting to the national federation), did not appear as significant.

On the contrary, the concentration of income is greater when the club is located in an urban area (URBAN), what can seem surprising with regard to the opportunity to develop new markets on these more populated and economically strong territories. It reminds us that competition between clubs is also harder for taking advantage of these potentialities. The logarithm of member fees (lnFEES) indicates that when there is concentration of income, it intervenes on the traditional products of the club (receipts of membership). To support this assertion, the calculation of the average percentage represented by member fees in the 
budget was made by categories of clubs, these categories been established according to the level of diversification of their resources. It appears that clubs with the most heterogeneous structure of revenues according to the Hirschman index have membership revenues that represent only $29.8 \%$ of their financial resources, while, for clubs with a strong concentration of revenues, in average $79 \%$ of their resources comes from member fees. On the contrary, business revenues show the vitality of the sports institutions because they reach a relative part of $25.7 \%$ on average in the budget of the most financially diversified clubs, against only $3.9 \%$ in those where resources are concentrated. The same report can be made for subsidies and sponsorship which, to a lesser extent, also prove the club's dynamism and its capacity to fetch financing other than subscriptions to the club. Associations renting the main facility that they use (RENTFACI) seems to have difficulties in diversifying their revenues what can be explained by their week capacity of negotiation with their financial partners as well as with the facility owner. Finally, the structure of expenditures seems to have an influence on the structure of revenues, and notably the part of the spending assigned to the payroll (\%WAGE) and to facilities (\%FACI). For the first factor relative to the wages, it is surprising that the part of remunerations in expenditures plays negatively on the diversity of clubs resources. It is a contribution of this paper to show that it is clubs that have a strong base in member's term, and thus a high level of member fees, which have the capacity to create employment.

\section{Comparative Analysis by Country}

The average structure of club budgets showed the importance of the relative share of subscriptions in associative funding (56.4\%); nevertheless, there were very significant differences between European countries (Table 4). Germany and Spain have fairly comparable funding methods, with very high membership participation through the payment of subscriptions (58.6\% and 69\%, respectively). France and The Netherlands show more diversified revenue profiles due to the importance of public subsidies (for France) and business revenue (for The Netherlands). It is really the high level of local authority support (especially, municipalities) which distinguishes France from the European average. The Czech Republic is atypical, as member contributions are limited to $15.2 \%$ of the total; it is, anyway, the only country where they do not represent the primary source of income. The importance of subsidies (33.5\%) in this country should be noted, a hangover from belonging to the Eastern Bloc; but what is also more surprising is the place given to business revenues and sponsorship.

Table 4. The Funding Structure of Sports Clubs Country by Country

\begin{tabular}{|l|c|c|c|c|c|c|}
\hline & \multicolumn{6}{|c|}{ Budget Structure } \\
\hline & Germany & Spain & France & The Netherlands & Czech Republic & All clubs \\
\hline Membership & $58.6 \%$ & $69.2 \%$ & $43.5 \%$ & $48.3 \%$ & $15.2 \%$ & $56.4 \%$ \\
\hline Subsidies & $8.6 \%$ & $8.8 \%$ & $31.9 \%$ & $5.3 \%$ & $33.5 \%$ & $14.1 \%$ \\
\hline Sponsorship & $13.2 \%$ & $12.5 \%$ & $6.7 \%$ & $11.5 \%$ & $22.3 \%$ & $11.8 \%$ \\
\hline Business revenues & $19.6 \%$ & $9.5 \%$ & $17.9 \%$ & $34.9 \%$ & $29.0 \%$ & $17.7 \%$ \\
\hline Total & $\mathbf{1 0 0 . 0 \%}$ & $\mathbf{1 0 0 . 0 \%}$ & $\mathbf{1 0 0 . 0 \%}$ & $\mathbf{1 0 0 . 0 \%}$ & $\mathbf{1 0 0 . 0 \%}$ & $\mathbf{1 0 0 . 0 \%}$ \\
\hline
\end{tabular}


In each of these countries, the factors influencing the ability of sports organisations to drum up new revenue are likely to differ, depending on the regulations and, especially, the socio-economic context. It became important, subsequently, to carry out a comparative analysis of the countries, based on the originally chosen model but applying ordinary least squares for each country separately. The results reported in Table 5 first show that the correlation coefficients $\left(\mathrm{R}^{2}\right)$ are generally good, since they lie between 0.344 for France and 0.8785 for Germany, with the exception of the Czech Republic where it is limited to 0.096 . The figures for this country should be treated with caution. Regarding firstly the factors that play a positive role on funding diversity, budget size is crucial in all countries, confirming that diversification accompanies an increase in overall club revenue. On the contrary, the amount of subscriptions is a factor of revenue concentration, which highlights that this item is the basis of the functioning of sports organisations. These are the only two variables that have a widespread influence in all countries.

In Germany, the club budget and the existence of a club-house play a positive role on revenue diversification, as does the increase in the number of volunteers, which confirms the importance of volunteering on the dynamism of German sports clubs. The German case shows that spending also has an impact on revenue diversification: a significant share of spending on equipment and travel expenses implies that clubs do seek additional funding from memberships.

Spain is a very sport-oriented country, where nearly one in two state that they do a sport, but where $75 \%$ of them do it outside of sports clubs and institutions ${ }^{17}$. The Spanish situation makes it possible to see, in particular, the factors that favour revenue concentration. As in Germany and The Netherlands, high member fees (FEESAV) lead to finances being based more on subscriptions. The importance of a club owning its own facilities or having them made available by public authorities can here be seen. When a club is forced to hire sports facilities (RENTFACI) and to devote a significant share of its spending to them (\%FACI), it remains even fewer financial resources to develop its business activity through sporting events and, especially, through non-sporting events which could generate other revenue than subscriptions. It also has less freedom in the use and development of these sports facilities. This has been borne out in France, The Netherlands and the Czech Republic.

For France, a number of variables appear to affect a club's funding structure. It should be noted that the organisation of events (EVESPO) is important, as has already been shown by Grossmann (2006) and Bourg and Nys (2012). Organising events is a significant source of funding in itself, but it also helps to attract a greater public and to enhance the club image for new partners (sponsors or patrons). It is possible, therefore, to talk of a double boost, with both direct and indirect effects. The mere fact of having a clubhouse (CLUBHOUSE variable) helps the holding of these events and extending the income of the sports association. As for Germany, the share of travel costs (\% TRANS) correlates positively with the Hirschman Index. Travel costs go hand in hand with taking part

${ }^{17}$ European Commission (2014, March 24) Eurobarometer of sport and physical activity, MEMO/14/207, goo.gl/irQ6Qc. 
in higher-level competitions and they go with the need to attract additional funding. Age (AGE) has an influence in opposing ways in France and The Netherlands; age appears to be a dynamic factor for French clubs, which are then able to attract new sources of revenue. The opposite is true for Dutch clubs, which are firmly based on subscriptions. Both the value of subscriptions (ln FEES) and the number of members (ln MEMBERS) are factors of revenue concentration in memberships, with the influence of the second variable only being found in The Netherlands.

The Czech Republic has a particular profile because it is a country from the ex-Soviet bloc and since, from a sporting standpoint, most clubs are multidisciplinary with up to thirty-five different disciplines. It should be noted here that the number of top-level athletes (HIGHNUM) and the fact that a club team plays at national or international level (HIGHLEV) impact on the structure of the club budget, which appears even more diverse. Top-level participation involves generating more substantial financial means and, at the same time, creating the opportunity to do so, since it gives the club visibility and renown. In these conditions, it is not surprising that the variable pertaining to organising sporting events (EVESPO) also works positively on income diversity. These are, at the same time, business revenue (ticketing, bar and catering, and merchandising, etc.), local authority subsidies, and any private partners that will be encouraged. From the spending point of view, in addition to the budget devoted to facilities (\%FACI), spending on salaries appear to be a factor of income concentration, which suggests that it is those clubs that have a solid base in terms of members and therefore subscriptions, that become employers. This result appears to contradict the literature, since employment in general is considered as a source of diversification (Tchernonog 2007, Downward et al. 2009).

The Netherlands, along with the Nordic countries, is one of the most sportoriented countries in Europe: $60 \%$ of the population states that it does some sport $^{18}$. In addition to the positive influence of the volunteering dynamic and the various elements previously mentioned, it should again be emphasised that the club being located in an urban area (URBAN) is a factor of revenue concentration in memberships.

${ }^{18}$ European Commission (2014, March 24) Eurobarometer of sport and physical activity, MEMO/14/207, goo.gl/irQ6Qc. 
Table 5. Explanatory Variables Country by Country (Hirschman Index as Dependant Variable)

\begin{tabular}{|c|c|c|c|c|c|c|c|c|c|c|c|c|c|}
\hline & & \multicolumn{10}{|c|}{ COUNTRIES } & & \\
\hline \multirow{2}{*}{\multicolumn{2}{|c|}{ EXPLANATORY VARIABLES }} & \multicolumn{2}{|c|}{ Germany } & \multicolumn{2}{|c|}{ Spain } & \multicolumn{2}{|c|}{ France } & \multicolumn{2}{|c|}{ The Netherlands } & \multicolumn{2}{|c|}{ Czech Republic } & \multicolumn{2}{|c|}{ ALL THE CLUBS } \\
\hline & & Parameter & P-value & Parameter & $\mathrm{P}$-value & Parameter & P-value & Parameter & $\mathrm{P}$-value & Parameter & P-value & Parameter & P-value \\
\hline \multicolumn{2}{|c|}{ CONSTANT } & 4.63182 & $<.0001^{* * *}$ & 4.35168 & $<.0001^{* * *}$ & 4.29275 & $<.0001^{* * *}$ & 4.82803 & $<.0001 * * *$ & 4.38507 & $<.0001 * * *$ & 4.3850 & $<.0001^{* * *}$ \\
\hline & \begin{tabular}{|l} 
AGE \\
URBAN \\
\end{tabular} & & & & & 0.00062698 & $0.0176^{* *}$ & $\begin{array}{c}-0.000996 \\
-0.03812 \\
\end{array}$ & $\begin{array}{c}0.0136^{* * *} \\
0.0399^{* *} \\
\end{array}$ & -0.02196 & 0.0284 & -0.0219 & $0.0284 * *$ \\
\hline MEMB & $\begin{array}{l}\text { In MEMBERS } \\
\text { MEMBSTAB }\end{array}$ & -0.04789 & 0.1177 & 0.05806 & $0.0527 *$ & $\begin{array}{c}-0.0000224 \\
-0.04607\end{array}$ & $\begin{array}{c}0.0226^{* * *} \\
0.0226^{* *}\end{array}$ & -0.000033 & 0.1141 & -0.01475 & 0.1495 & -0.01475 & 0.1495 \\
\hline LEV & $\begin{array}{l}\text { HIGHNUM } \\
\text { HIGHLEV }\end{array}$ & & & & & 0.03017 & 0.1438 & & & $\begin{array}{l}0.00014 \\
0.04673 \\
\end{array}$ & $\begin{array}{c}0.0140^{* *} \\
0.0002 * * * \\
\end{array}$ & $\begin{array}{c}0.0001 \\
0.04673 \\
\end{array}$ & $\begin{array}{c}0.0140^{* *} \\
0.0002^{* * *}\end{array}$ \\
\hline STRUC & \begin{tabular}{|l|} 
CLUBHOUSE \\
VOLINC \\
\end{tabular} & $\begin{array}{l}0.08685 \\
0.06175 \\
\end{array}$ & $\begin{array}{c}0.0072^{* * *} \\
0.0896^{*} \\
\end{array}$ & -0.03453 & $0.0863 *$ & 0.05916 & $0.0012^{* * *}$ & 0.04934 & $0.0193 * *$ & 0.02050 & $0.0643^{* *}$ & 0.2050 & $0.0643^{*}$ \\
\hline REV & \begin{tabular}{|l} 
In BUDG \\
FEESAV \\
In FEES \\
RENTFACI \\
EVESPO \\
OTHEREV
\end{tabular} & $\begin{array}{c}0.30204 \\
-0.00140 \\
-0.28344\end{array}$ & $\begin{array}{c}<.0001^{* * *} \\
0.0017^{* * *} \\
<0.0001^{* * *}\end{array}$ & $\begin{array}{c}0.13805 \\
-0.00103 \\
-0.13823 \\
-0.05335\end{array}$ & $\begin{array}{c}<.0001^{* * *} \\
0.0552^{*} \\
<.0001^{* * *} \\
0.0010^{* * *}\end{array}$ & $\begin{array}{l}0.06966 \\
-0.08161 \\
0.07230 \\
0.03837\end{array}$ & $\begin{array}{c}<.0001^{* * *} \\
<.0001^{* * *} \\
0.0032^{* * *} \\
0.0276^{* *}\end{array}$ & $\begin{array}{c}0.19023 \\
-0.00046 \\
-0.13433\end{array}$ & $\begin{array}{c}<.0001^{* * *} \\
0.0243^{* *} \\
<.0001^{* * *}\end{array}$ & $\begin{array}{c}-0.12056 \\
-0.04440 \\
0.03418\end{array}$ & $\begin{array}{l}<.0001 * * * \\
<.0001 * * * \\
0.0001 * * * \\
0.0085^{* * *}\end{array}$ & $\begin{array}{c}0.1234 \\
-0.12056 \\
-0.0444 \\
0.03418\end{array}$ & $\begin{array}{l}<.0001^{* * *} \\
<.0001^{* * *} \\
0.0001^{* * *} \\
0.0085^{* * *}\end{array}$ \\
\hline EXP & $\begin{array}{l}\text { \%WAGE } \\
\% \text { EQUI } \\
\% \text { FACI } \\
\% \text { TRANS }\end{array}$ & $\begin{array}{l}0.20836 \\
0.70552\end{array}$ & $\begin{array}{l}0.0395 * * \\
0.0719 *\end{array}$ & -0.10664 & $0.0238^{* *}$ & $\begin{array}{c}-0.25449 \\
0.15690\end{array}$ & $\begin{array}{l}0.0091^{* * *} \\
0.0094^{* * *}\end{array}$ & -0.04805 & 0.1455 & $\begin{array}{l}-0.05393 \\
-0.05929\end{array}$ & $\begin{array}{c}0.0039 * * * \\
0.0102 * *\end{array}$ & $\begin{array}{l}-0.05393 \\
-0.05929\end{array}$ & $\begin{array}{c}0.0039 * * * \\
0.0102^{* *}\end{array}$ \\
\hline & & \multicolumn{2}{|c|}{$\mathrm{n}=57$} & $\begin{aligned} \mathrm{n} & =5 \\
\boldsymbol{R}^{\mathbf{2}} & =\mathbf{0 . 4}\end{aligned}$ & & $\begin{array}{r}\mathrm{n}=4 \\
\boldsymbol{R}^{\mathbf{2}}=\mathbf{0}\end{array}$ & & \multicolumn{2}{|c|}{$\begin{array}{c}\mathrm{n}=203 \\
R^{2}=\mathbf{0 . 5 7 4 7}\end{array}$} & \multicolumn{2}{|c|}{$\begin{array}{c}\mathrm{n}=218 \\
R^{2}=0.096\end{array}$} & \multicolumn{2}{|c|}{$\begin{array}{c}\mathrm{n}=1454 \\
\boldsymbol{R}=\mathbf{0 . 3 4 7 3}\end{array}$} \\
\hline
\end{tabular}

* Significant at a threshold of $10 \% \quad$ ** Significant at a threshold of 5\% *** Significant at a threshold of $1 \%$

Note: the coefficient of variables OMNI (multisport club), \%FEM (percentage of women), MEMBINC (increase in the number of members), LAWLEV (club involved in local or regional competitions), EMPLOY (number of employees in the club), VOLSTAB (stability of the number of volunteers), \%FEDE (percentage of expenditures benefiting to the national federation), did not appear as significant. 


\section{Comparative Analysis by Sport}

The structure of financing by sport is given in Table 6. Football differs clearly from the other sports, since it is able to fund itself largely through having generated significant business revenue (both sporting and non-sporting events), as well as by sponsorship. Club revenues appear to be strongly diversified with less dependence on subscriptions (the tariffs are low, which strengthens the popular dimension of this sport) and public subsidies.

Those associations offering athletics and basketball also have a relatively diversified funding structure; the difference with football is that the share of public funding is more significant (more than double), while the relative shares of sponsorship and business revenue are significantly lower. This can be explained by the ability of these sports, which is certainly significant but is more limited, to develop their revenues through the market (partnerships and business income) and a greater dependence on public funds. On the other hand, gymnastics and swimming have funding that is concentrated on member participation, representing nearly two-thirds of the total, their revenue then dependent on subsidies for about a quarter. However, these associations have great difficulty in attracting businesses (the share for sponsorship is less than 5\%) and in generating financial products related to their business; this finding may be partly attributed to a lack of media coverage.

Finally, tennis is the sport in which income distribution is the most concentrated. It is, therefore, more dependent on subscriptions (nearly $70 \%$ ), with the amounts often being high compared to sports like football. The economic model of tennis is peculiar, as the second revenue source is a business revenue (tournaments are systematically organised in tennis clubs and are often accompanied by numerous festive events) and then sponsorship, while subsidies have a weight of less than 5\%. It can be seen that each sport is based on a specific funding model and we can now examine the determinants.

Table 6. Funding Structure of Sports Clubs Sport by Sport

\begin{tabular}{|l|c|c|c|c|c|c|c|}
\hline & \multicolumn{7}{|c|}{ Budget Structure } \\
\hline & Football & Basketball & Gymnastics & Swimming & Tennis & Athletics & All clubs \\
\hline Membership & $32.9 \%$ & $41.7 \%$ & $56.9 \%$ & $61.9 \%$ & $69.7 \%$ & $30.2 \%$ & $56.4 \%$ \\
\hline Subsidies & $15.0 \%$ & $32.4 \%$ & $26.3 \%$ & $24.8 \%$ & $4.5 \%$ & $34.3 \%$ & $14.1 \%$ \\
\hline Sponsorship & $23.1 \%$ & $12.4 \%$ & $4.4 \%$ & $3.0 \%$ & $10.0 \%$ & $15.8 \%$ & $11.8 \%$ \\
\hline $\begin{array}{l}\text { Business } \\
\text { revenues }\end{array}$ & $29.0 \%$ & $13.5 \%$ & $12.4 \%$ & $10.3 \%$ & $15.8 \%$ & $19.7 \%$ & $17.7 \%$ \\
\hline Total & $\mathbf{1 0 0 . 0 \%}$ & $\mathbf{1 0 0 . 0 \%}$ & $\mathbf{1 0 0 . 0 \%}$ & $\mathbf{1 0 0 . 0 \%}$ & $\mathbf{1 0 0 . 0 \%}$ & $\mathbf{1 0 0 . 0 \%}$ & $\mathbf{1 0 0 . 0 \%}$ \\
\hline
\end{tabular}


Table 7. Explanatory Variables Sport by Sport (Hirschman Index as Dependant Variable)

\begin{tabular}{|c|c|c|c|c|c|c|c|c|c|c|c|c|c|c|c|}
\hline \multirow{3}{*}{\multicolumn{2}{|c|}{$\begin{array}{c}\text { EXPLANATORY } \\
\text { VARIABLES }\end{array}$}} & \multicolumn{14}{|c|}{ SPORTS } \\
\hline & & \multicolumn{2}{|c|}{ TENNIS } & \multicolumn{2}{|c|}{ SWIMMING } & \multicolumn{2}{|c|}{ GYMNASTICS } & \multicolumn{2}{|c|}{ FOOTBALL } & \multicolumn{2}{|c|}{ BASKET-BALL } & \multicolumn{2}{|c|}{ ATHLETICS } & \multicolumn{2}{|c|}{ ALL THE CLUBS } \\
\hline & & Parameter & $P$-value & Parameter & P-value & Parameter & P-value & Parameter & $\mathrm{P}$-value & Parameter & P-value & Parameter & P-value & Parameter & P-value \\
\hline \multicolumn{2}{|c|}{ CONSTANT } & 4.25301 & $<.0001^{* * *}$ & 4.53797 & $<.0001^{* * *}$ & 4.63250 & $<.0001^{* * *}$ & $4.39467 * * *$ & $<.0001$ & 4.27284 & $<.0001^{* * *}$ & 4.13599 & $<.0001^{* * *}$ & 4.3850 & $<.0001^{* * *}$ \\
\hline CARAC & $\begin{array}{l}\text { OMNI } \\
\text { AGE } \\
\text { URBAN }\end{array}$ & & & & & & & -0.06911 & $0.0006 * * *$ & -0.03668 & $0.0683^{*}$ & $\begin{array}{l}-0.11301 \\
0.00208 \\
-0.11791\end{array}$ & $\begin{array}{c}0.0188^{* *} \\
0.0059^{* * *} \\
0.0246 * *\end{array}$ & -0.0219 & $0.0284^{* *}$ \\
\hline MEMB & $\begin{array}{l}\text { In MEMBRES } \\
\% \text { FEM } \\
\text { MEMAUG } \\
\text { MEMSTAB }\end{array}$ & $\begin{array}{c}0.000068 \\
0.08271 \\
\\
-0.03593 \\
\end{array}$ & $\begin{array}{c}0.0052^{* * *} \\
0.1141 \\
0.0555^{*}\end{array}$ & $\begin{array}{l}-0.000029 \\
-0.07914\end{array}$ & $\begin{array}{l}0.0375^{* *} \\
0.0018^{* * *}\end{array}$ & 0.04104 & 0.1246 & -0.04913 & $0.0156^{* *}$ & & & $\begin{array}{l}-0.000027 \\
-0.16367\end{array}$ & $\begin{array}{c}0.0201 \\
0.0033^{* * *}\end{array}$ & -0.01475 & 0.1495 \\
\hline NIV & $\begin{array}{l}\text { HAUTNOM } \\
\text { HAUTNIV }\end{array}$ & 0.05443 & $0.0237^{* *}$ & 0.06783 & $0.0068^{* * *}$ & & & 0.00019 & $0.0198^{* *}$ & 0.00053 & $0.0013^{* * *}$ & & & $\begin{array}{c}0.0001 \\
0.04673 \\
\end{array}$ & $\begin{array}{c}0.0140^{* *} \\
0.0002^{* * *}\end{array}$ \\
\hline STRUC & $\begin{array}{l}\text { CLUBHOUSE } \\
\text { EMPLOI } \\
\text { BENEAUG } \\
\text { BENESTAB }\end{array}$ & $\begin{array}{c}0.03875 \\
-0.00328 \\
\\
0.04270 \\
\end{array}$ & $\begin{array}{c}0.1119 \\
0.0916^{*} \\
0.0250^{* *}\end{array}$ & & & & & $\begin{array}{l}0.05732 \\
0.07624\end{array}$ & $\begin{array}{l}0.0173^{* *} \\
0.0026 * * *\end{array}$ & & & 0.26011 & $<.0001^{* * *}$ & 0.2050 & $0.0643^{*}$ \\
\hline REV & $\begin{array}{l}\text { In BUDG } \\
\text { In COTIS } \\
\text { LOCEQUI } \\
\text { EVESPO } \\
\text { AUTREVE } \\
\end{array}$ & $\begin{array}{l}0.15016 \\
-0.17310\end{array}$ & $\begin{array}{l}<.0001^{* * *} \\
<.0001^{* * *}\end{array}$ & $\begin{array}{c}0.17762 \\
-0.16453 \\
-0.08688 \\
0.05398 \\
-0.05938 \\
\end{array}$ & $\begin{array}{c}<.0001^{* * *} \\
<.0001^{* * *} \\
0.0022^{* * *} \\
0.0414^{* *} \\
0.0280^{* *}\end{array}$ & $\begin{array}{l}0.29063 \\
-0.26957\end{array}$ & $\begin{array}{l}<<.0001^{* * *} \\
<.0001^{* * *}\end{array}$ & $\begin{array}{l}0.04443 \\
-0.02869\end{array}$ & $\begin{array}{c}0.0031^{* * *} \\
0.0226^{* *}\end{array}$ & $\begin{array}{l}0.13044 \\
-0.13803\end{array}$ & $\begin{array}{l}<.0001^{* * *} \\
<.0001^{* * *}\end{array}$ & & & $\begin{array}{c}0.1234 \\
-0.12056 \\
-0.0444 \\
0.03418\end{array}$ & $\begin{array}{l}<.0001^{* * *} \\
<.0001^{* * *} \\
0.0001^{* * *} \\
0.0085^{* * *}\end{array}$ \\
\hline \multirow[t]{2}{*}{ DEP } & $\begin{array}{l}\% \text { SAL } \\
\% \text { MAT } \\
\% \text { INSTAL }\end{array}$ & & & & & & & & & -0.07923 & $0.0084^{* * *}$ & 0.74067 & $0.0024^{* * *}$ & $\begin{array}{l}-0.05393 \\
-0.05929 \\
\end{array}$ & $\begin{array}{l}0.0039 * * * \\
0.0102 * *\end{array}$ \\
\hline & & $\begin{array}{c}\mathrm{n}=257 \\
R^{2}=0.5135\end{array}$ & & $\begin{array}{c}\mathrm{n}=236 \\
R^{2}=0.5233\end{array}$ & & $\begin{array}{c}\mathrm{n}=222 \\
R^{2}=0.5654\end{array}$ & & $\begin{aligned} \mathrm{n} & =413 \\
R^{2} & =0.1701\end{aligned}$ & & $\begin{aligned} \mathrm{n} & =270 \\
R^{2} & =0.4735\end{aligned}$ & & $\begin{array}{c}\mathrm{n}=56 \\
R^{2}=0.6601\end{array}$ & & $\begin{array}{c}\mathrm{n}=1454 \\
R^{2}=0.3473\end{array}$ & \\
\hline
\end{tabular}

Note: the coefficients of variables LAWLEV (club involved in local or regional competitions), FEESAV (average member fees), \%TRANS (percentage

of the spending dedicated to transportation), \%FEDE ("percentage of the spending benefiting to the national federation), did not appear as significant. 
Regressions were performed sport by sport, on the same model as previously mentioned, results are reported in Table 7 . The correlation coefficient $\left(\mathrm{R}^{2}\right)$ was generally at a high level close to (for basketball) or exceeding (for tennis, swimming, gymnastics and athletics) 0.5 . Football is an exception, since $\mathrm{R}^{2}$ was limited to 0.17 , which indicated that variables other than those discussed heavily influenced the budget structure. The positive correlation between the size of the budget (ln BUDG) and the level of financial diversification was confirmed, as was the negative relationship with subscriptions (ln FEES). Only athletics did not follow this general rule. Some distinctive signs in each sport appeared; they will be summarised here.

For tennis, the number of members (ln MEMBERS) was positively correlated with the income diversification, unlike in swimming and athletics. Thus, the amount of subscriptions increased with the number of members, which could have led to a concentration of club revenue in memberships; however, in reality, the size reached by the club allowed it to diversify its funding: it could set up more sporting and non-sporting events, which were sources of earned income and offered more visibility to business partners, which led to additional sponsorship revenue. The presence of athletes performing at high-level in the club (HIGHLEV) made it possible to have a sporting spectacle, which led to differentiated cash flows (admissions, sale of related products and consumption during matches, etc.). Having a stable rather than a declining system of volunteers (VOLSTAB) was also involved in mixing revenues, as volunteers were able to be used to raise revenue other than by membership. Somewhat surprisingly, having employees (EMPLOY) appeared, once again, not to necessarily accompany using new funding methods: volunteers were, therefore, more of a determinant than employees, from this point of view. It may be surprising that the presence of a clubhouse (CLUBHOUSE) was not more important, but as virtually all the clubs have one, it did not make it a classification variable. The feminisation of clubs (\%FEM) seemed to be able to influence positively revenue diversity, but, at the $10 \%$ level, the coefficient was not significant, despite the observation by Tabariés and Tchernonog (2004).

As far as swimming was concerned, the budget (ln BUDG), the organisation of sporting events (EVESPO), and the participation of clubs in top-level competitions (HIGHLEV) were explanations for revenue diversity. It could be seen that the coefficient associated with the budget between tennis (0.15) and swimming (0.17) was close, which meant that the degree of diversification according to the size of the budget is similar between the two sports. Being obliged to hire the sports facility that is primarily used (RENTFACI) was a factor of revenue concentration in swimming, which was not the case in any of the other sports studied. The consequences of swimming pools reaching saturation point could be thus measured, as they prevented sports associations from developing and diversifying their operations.

Few variables emerged that explained revenue diversification in gymnastics clubs. There was still a strong correlation between the size of the budget (ln BUDG) and the degree of diversification. The associated coefficient was 0.29, which was significantly higher than that obtained for tennis and swimming. Size, therefore, had a strong effect on budget structure for gymnastics. As for all other 
sports, except athletics, the amount of subscriptions (ln FEES) was a factor of revenue concentration.

For football, the most represented sport in the sample with 617 clubs, we again found the general lessons drawn from the regressions on all the sports studied. The number of top athletes (HIGHNUM), the club budget (ln BUDG) and the presence of a clubhouse (CLUBHOUSE) are indisputable determinants of revenue diversity in football clubs. However, their respective roles must be differentiated because the coefficient is low for the variable representative of toplevel compared to the variable relating to the club budget. Football, more than any other discipline, is a sport that is largely based on volunteers, which explains that the growth of volunteering (VOLINC) is essential in acceding dynamically to new sources of funding. On the other hand, the Hirschman Index decreases (which means a concentration of club income) with an urban location (URBAN), income from subscriptions (ln FEES) and an increase in the number of members (MEMBINC). This confirms that concentration, when it occurs, is on subscriptions and, more widely, on revenue from members.

As far as basketball was concerned, the factors of diversification were the size of the budget (ln BUDG) and the development of a top-level team (HIGHLEV), while the importance of subscriptions, expressed in a logarithm (ln FEES), and of the urban location (URBAN), favoured the concentration of club revenues. As for football and athletics, being located in an urban area was not necessarily a factor that facilitated the search for other income than subscriptions. The peculiarity of basketball probably focuses on the role that spending on salaries (\%WAGE) plays; the greater its relative weight, the more the budget structure is concentrated. This was consistent with what was observed about the influence of the variable concerning employment (EMPLOY) for tennis.

The case of athletics is very particular, as the determinants of the budget structure were not necessarily those identified for the other sports. It was the only sport for which the size of the budget did not seem to positively influence revenue diversity and, where there was concentration, it was not necessarily on subscriptions, since the corresponding coefficient (the "In FEES" variable) was not significant. The variable relating to the age of the association (AGE) seemed to have a positive effect on the search for new funding. Some clubs in the sample date from the early $20^{\text {th }}$ century: their experience and their local roots seemed an asset in bringing in new revenue sources. However, the coefficient corresponding to this factor remained low, while that relating to the existence of a clubhouse (CLUBHOUSE) was high. The variable reflecting the percentage of the budget devoted to purchasing equipment (\%EQUI) had a positive impact on revenue diversity. This could be explained by the importance of the equipmentthat a club must have, with the specific requirements of many sports (shot-putting/discus or javelin throwing, high jumps and race-tracks) that forced it to diversify its sources of funding. Conversely, the fact of being a multisport club (OMNI), located in an urban area (URBAN) and seeing increased membership (MEMBINC) were factors of revenue concentration. 


\section{Conclusion}

Developing indicators of revenue concentration, therefore, made it possible to offer a novel analysis of the funding structure of European sports clubs. The regressions carried out by ordinary least squares and the "step by step" procedure led to results that were partially consistent with the still limited existing literature on the subject. Thus, sports associations showed that the higher the club budget, the more diversified the composition of revenues. Furthermore, it has been proved that when there was a concentration of revenues, it happened with subscriptions, confirming the traditional model of the sports club. Overall, increasing the number of volunteers was, to a varying degree dependent on the sport and the country, a factor for revenue diversity, which confirmed the conclusions of the study by Andreff et al. (1995). As Clivaz mentioned (2005), organising sporting events has become a means of varying club revenues, just like the number of top-level athletes and playing in national and international competitions.

Other results were more unusual, but can be explained by the operation of sports clubs. With regard to the work of Tchernonog (2007), it could be expected that the presence of employees was conducive to obtaining new funding and would result in an increase in the size and diversity of the budget. However, this was not confirmed, since both the variables relating to employment and that reflecting the significance of spending on the payroll, could not be statistically shown to be a source of diversification. It could be concluded that it was the most robust clubs, which have a solid base in terms of subscriptions, that were able to recruit employees; but they did not necessarily then go on to seek new revenues. The urban location of a club seemed to be a handicap in trying to gather new revenues: the reason may well be the high density of clubs competing to obtain funding from businesses. The age of the club and, therefore, its experience and local roots, did not prove to impact significantly on the composition of financial resources; probably because new associative structures may really be enjoying a new dynamism. Finally, it was surprising to note that organising non-sporting events did not appear to play an important role in allowing a club to vary its revenues, perhaps because of non-profit making aspect of these actions.

In addition, several research opportunities could be mentioned. A bigger sample of the clubs surveyed would give a more general vision of the situation in European sport and would give a typology of sports and countries, according to the determinants of the structure of club budgets. Similarities have already appeared (in tennis and swimming: the level of competition and organisation of sporting events are discriminating factors). Going beyond these first lessons, the work could be enriched by including complementary variables reflecting the socio-demographic characteristic of the areas where the clubs are to be found. That would probably help to improve the explanatory power of the model. 


\section{References}

Amis J, Slack T (1996) The size structure impact. Journal of Sport Management 10(1): 76-86.

Amit R, Livnat J (1988) Diversification Strategies - Business Cycles and Economic Performance. Strategic Management Journal 9(2): 99-100.

AMNYOS (2008) Public and private founding of sport study. Report in the context of the French EU Presidency. Ministère de la Santé, de la Jeunesse et des Sports (Ministry for Health, Youth, and Sport). Unpublished, Paris.

Andreff W (2007) New Perspectives in Economics of Sport: A European View. In ML Klein, M Kurscheidt (Eds.), Neue Perspektiven ökonomisher Sportforschung (New Perspectives in Sport Economics). Schorndorf: Hofmann, pp. 36-65.

Andreff W (2012) Mondialisation économique du sport (Globalisation of the Sport Industry). Bruxelles: De Boeck.

Andreff W, Bourg J-F, Halba B, Nys J-F (1995) Economic Impact and Financing of Sport in Europe. Strasbourg: Dalloz.

Andreff W, Montel J, Dutoya J (2009) Le modèle européen de financement du sport: quels risques? (The European Model for Sport Financing: which risks?). Revue Juridique et Economique du Sport (90): 75-85.

Anheier HK (2005) Non-Profit Organizations - Theory, Management, Policy. Oxon: Routledge.

Attaran M, Zwick M (1987) The Effect of Industrial Diversification on Employment Income: A Case Study. Quarterly Review of Economics Business 27(4): 38-54.

Augustin J-P, Garrigou A (1985) Le rugby démêlé (The Economics of Rugby). Bordeaux: Le Mascaret.

Batsch L (1993) La diversité des activités des groupes industriels (Diversity of the activities of the industrial groups). Revue d'Economie Industrielle 66(1): 33-40.

Bednarik J, Kolar E, Jurak G (2010) Analysis of the sports services market in Slovenia. Kinesiology 42(2): 142-152.

Ben Hammouda H, Karingi N, Sadni-Jallab M (2006) La diversification: vers un nouveau paradigme pour le développement de l'Afrique (Diversification : toward a new paradigm for the development of Africa). Unpublished, Centre Africain de Politique Commerciale.

Borzaga C, Defourny J (Eds.) (2001) The Emergence of Social Enterprise. London \& New York: Routledge.

Bourg J-F, Nys J-F (2012) Financement des clubs sportifs et stratégies des collectivités territoriales (Sporting clubs financing and strategies of public authorities). Grenoble: Editions Territorial.

Breuer C (2007) An analysis of sports clubs in Germany - Report 2005/2006. In C Breuer (Eds.), Sportentwicklungsbericht für Deutschl (Report on sport development in Germany). Köln: Sport und Buch Strauß.

Breuer C (2009) Sport Development Report for Germany 2007/2008 - Analysis of the sports club's situation in Germany (Abbreviated Version). Strauß, Köln: Sportverlag.

Breuer C, Hallmann K, Wicker P, Feilerd S (2010) Socio-economic patterns of sport damaging. European Review of Ageing Physical Activity 7(2): 61-70.

Breuer C, Pawlowski T (2011) Socioeconomic Perspectives in Physical Activity Aging. European Reviews of Aging Physical Activity 8(89): 53-56.

Chantelat P (2001) Les logiques socio-économiques des clubs sportifs amateurs Socio-economic logic of amateur sports clubs. Revue STAPS 2(55): 61-78. 
Clivaz C (2005) Durabilité de l'événement sportif: quelles implications pour les collectivités territoriales? (Sporting events durability: recommandations for public decision makers). Conférence internationale sur les politiques d'accueil d'événements sportifs, May 2005, Lausanne, USA.

Collette C, Pigé B (2007) Economie sociale et solidaire: Gouvernance et contrôle (The social economy: governance and control). Paris: Dunod.

CEGES - Conseil des Entreprises et groupements de l'économie sociale (Council of companies, employers and groups of the social economy) (1995) La charte de l'économie sociale - Charter of Social Economy. 10 May 1995. www.ceges.org.

Cordery C, Baskerville R (2013) Three Models, one goal: assessing financial vulnerability in New Zealand Amateur Sport Clubs. Sport Management Review 16(2): 186-199.

Defourny J, Laville J-L (2007) Pour une économie sociale revisitée (Another perspective on voluntary sector). La revue nouvelle 1(2): 78-83.

De Knop P, Van Hoecke J, De Bosscher V (2004) Quality Management in Sports Clubs. Sport Management Review 7(1): 57-77.

Downward P, Dawson A, Dejonghe T (2009) Sport Economics - Theory, Evidence Policy. Oxford: Elsevier.

Eurostrategies (2011a, June 27) Study on the Funding of Grassroots Sports in the EU With a Focus on the Internal Market Aspects Concerning Legislative Frameworks and Systems of Financing, Final Report, Volume I. Brussels: Amnyos, the Centre de Droit et d'Economie du Sport (CDES), The Deutsche Sporthochschule Köln, and the European Olympic Committee (EOC) EU Office. goo.gl/GVcTwF.

Eurostrategies (2011b, June 27) Study on the Funding of Grassroots Sports in the EU With a Focus on the Internal Market Aspects Concerning Legislative Frameworks and Systems of Financing, Final Report, Volume II - Country Reports. Brussels: Amnyos, the Centre de Droit et d'Economie du Sport (CDES), The Deutsche Sporthochschule Köln, and the European Olympic Committee (EOC) EU Office. goo.gl/XGDFiF.

Evers A, Laville J-L (2004) The third sector in Europe. Northampton, USA: Edward Elgar Publishing.

Greenlee JS, Trussel JM (2000) Predicting the financial vulnerability of charitable organizations. Nonprofit Management and Leadership 11(2): 199-210.

Grossmann M (2006) Education nonmarket outcomes. In EA Hanushek, F Welsh (Eds.), Handbook of the Economics of Education, 1, Chapter 10. London: Elsevier.

Heinemann K (Eds.) (1999) Sport Clubs in Various European Countries. Shorndorf: Hoffmann.

Hirschman AO (1945) National Power the Structure of Foreign Trade. Berkeley: University of California Press.

Horch H-D (1998) Self-Destroying processes of sport clubs in Germany. European Journal of Sport Management 5(1): 46-58.

Humphreys B, Ruseski J (2009) Estimates of the dimensions of sports market in the USA. International Journal of Sport Finance 4(3): 94-113.

Ion J (2001) Clubs d'athlétisme et professionnalisation: Une étude de cas (Track and field clubs professionals: A Case Study). In $\mathrm{P}$ Chantelat (Eds.), $L a$ professionnalisation des organisations sportives (Managing sporting organizations). Paris: L'Harmattan.

Kingston JL (1976) Export concentration export performance in developing countries 1954-67. The Journal of Development Studies 12(4): 311-319. 
Kingma BR (1993) Portfolio theory and nonprofit financial stability. Nonprofit and Voluntary Sector Quarterly 22(2): 105-119.

Lipietz A (2000) Rapport sur l'économie sociale et solidaire (Report on the social economy). Cahiers du Laboratoire de recherche sur les pratiques et les politiques sociales $1(1)$ : 12-35.

Massell BF (1970) Export Instability Economic Structure. The American Economic Review 60(4): 618-630.

Michon B, Ohl F, Faber C (1987) The price of sports for the consumer. Systemic approach to sports: determinations comparative analysis of financial cost of sports for the consumer. Rapport FRT. Unpublished, Paris.

Novotny J (2008) Problems with evaluating voluntary work in sports. Working Paper, 10th Annual IASE Conference, May 3-5, Gijón, Spain.

Pawlowski T, Breuer C (2011) The demand for sport and recreational services: Empirical Evidence for Germany. European Sport Management Quarterly 11(1): 5-34.

Ruseski JE, Humphreys B, Hallmann K, Breuer C (2011) Family structure, time constraints, sport participation. European Review Against Physical Activity 8(3): 57-68.

Ross S, Westerfield R, Jaffe J (2008) Corporate Finance. New-York: McGraw Hill Irwin.

Skirstad B, Chelladuraï P (2011) For "love" money: A sport club's innovative response to multiple logics. Journal of Sport Management 25(4): 339-353.

Slack T (1997) Understanding Sport Organizations - The Application of the Organization Theory. London: Human Kinetics.

Stanley DI, Bunnag S (2001) A new look at the benefits of diversification: Lessons from Central America. Applied Economics 33(11): 1369-1383.

Svedberg P (1991) The Export Performance of Sub-Saharan Africa Economic Development Cultural Change 39(3): 549-566.

Tabariés E, Tchernonog V (2004) Les femmes dans les associations: Premiers résultats de l'enquête sur les dirigeants bénévoles des associations (Women and clubs: First results of the survey on voluntary clubs managers). Laboratoire de recherche Matisse - CNRS, February 2004, Paris.

Tchernonog V (2007) Les associations en France, poids, profil et évolutions: Financements publics et privés, emplois salariés et travail bénévole, gouvernance (Associations in France, economic weight and development: public and private financing, volunteers and employees, governance). Association pour le développement de la documentation sur l'économie sociale, November 2007, Paris, www.apes-npdc.org.

Tchernonog V (2013) Les associations entre crise et mutations: les grandes évolutions (Associations, crisis or mutation: major changes). Association pour le développement de la documentation sur l'économie sociale, October 2013, Paris, www.apes-npdc.org.

Trussel JM (2002) Revisiting the prediction of financial vulnerability. Nonprofit Management and Leadership 13(1): 17-31.

Wicker P, Breuer C, Hennigs B (2012) Understanding the interactions among revenue categories using elasticity measures - Evidence from a longitudinal sample of non-profit sports clubs in Germany. Sport Management Review 15(3): 722-738.

Wicker P, Breuer C, Pawlowski T (2010) Are Sports Club Members big Spenders Findings from Sport Specific Analyses in Germany. Sport Management Review 13(3): 214-224. 
Wicker P, Breuer C, Pawlowski T (2009) Promoting Sport for all to Age-specific Target Groups: the Impact of Sport Infrastructure. European Sport Management Quarterly 9(2): 103-118.

Wicker P, Longley N, Breuer C (2015) Revenue Volatility in German Nonprofit Sports Clubs. Nonprofit and Voluntary Sector Quarterly 44(1): 5-24. 